\title{
Nitrogen management, cultivars and growing environments on wheat grain quality
}

\author{
Raphael R. Silva ${ }^{1}$, Claudemir Zucareli², Inês C. de B. Fonseca², Carlos R. Riede ${ }^{3} \&$ Diego Gazola $^{4}$ \\ ${ }^{1}$ Tropical Melhoramento e Genética. Londrina, PR, Brasil. E-mail: rossi.raphael@outlook.com - ORCID: 0000-0003-4960-6954 \\ ${ }^{2}$ Universidade Estadual de Londrina/Centro de Ciências Agrárias/Departamento de Agronomia. Londrina, PR, Brasil. E-mail: claudemircca@uel.br - \\ ORCID: 0000-0002-5260-0468; inescbf@uel.br - ORCID: 0000-0003-0129-8534 \\ ${ }^{3}$ Instituto Agronômico do Paraná. Londrina, PR, Brasil. E-mail: criede@iapar.br - ORCID: 0000-0002-9932-6689 \\ ${ }^{4}$ Universidade Estadual de Londrina. Londrina, PR, Brasil. E-mail: gazolad@gmail.com (Corresponding author) - ORCID: 0000-0002-1375-6179
}

\begin{abstract}
The aim of this study was to evaluate the influence of nitrogen $(\mathrm{N})$ fertilization, environment and cultivars on the protein concentration, sodium dodecyl sulfate sedimentation test (SDSS) volume and falling number in wheat. The experimental design was a randomized blocks in split plot scheme with four repetions. Four wheat genotypes were evaluated under six N managements in four enviroment (subplots). The wheat genotypes evaluated were IPR Catuara TM, BRS Gaivota, Quartzo and CD 120. Protein concentration, SDS sedimentation test, falling number and grain yield were evaluated. Combined analysis of variance for the four environment was performed and means were compared by Tukey test at $p \leq 0.05$. The environmental effect is greater than the genotype and $\mathrm{N}$ effects on protein concentration. The increase in protein concentration reduces grain yield of the cultivars tested. SDSS and falling number in wheat are influenced by the interaction between cultivar and environment and also by the $\mathrm{N}$ management. The protein concentration of grain has low influence on SDS sedimentation volume, so the topdressing $\mathrm{N}$ management has less accentuated effect on this response variable. The falling number does not vary among cultivars when the environment is suitable to pre-harvest sprouting. The use of topdressing $\mathrm{N}$ influences the falling number in wheat.
\end{abstract}

Key words: Triticum aestivum L., grain yield, urea, ammonium sulfate

\section{Manejo de nitrogênio, cultivares e ambientes de cultivo na qualidade de grãos de trigo}

\begin{abstract}
RESUMO: O objetivo deste estudo foi de avaliar a influência da adubação nitrogenada, do ambiente e cultivares no teor de proteínas, o volume de sedimentação com dodecil sulfato de sódio (SDSS) e no número de queda em trigo. O delineamento experimental foi em blocos ao acaso em esquema de parcelas subdivididas, em quatro repetições foram avaliadas cultivares de trigo IPR Catuara TM, BRS Gaivota, Quartzo e CD 120 em seis manejos do nitrogênio em quatro ambientes. Foram realizadas as avaliações do teor de proteínas, teste de sedimentação com dodecil sulfato de sódio, número de queda e produtividade de grãos. Foi realizada análise de variância conjunta para os quatro ambientes e as médias foram comparadas pelo teste de Tukey, $\mathrm{p} \leq 0,05$. $\mathrm{O}$ efeito do ambiente é superior ao efeito de nitrogênio e de cultivares sobre o teor de proteínas. O incremento no teor de proteínas reduz a produtividade de grãos das cultivares. O SDSS e o número de queda em trigo são influenciados pela interação entre cultivar e ambiente e também pelo manejo do nitrogênio. $O$ teor de proteínas no grão tem baixa influência sobre o volume de sedimentação com dodecil sulfato de sódio, logo o manejo do nitrogênio em cobertura apresenta efeito menos acentuado para essa variável resposta. O número de queda não varia entre cultivares quando o ambiente é propício à germinação na espiga. A utilização de nitrogênio em cobertura influência o número de queda em trigo.
\end{abstract}

Palavras-chave: Triticum aestivum L., produtividade de grãos, ureia, sulfato de amônio 


\section{INTRODUCTION}

There are several variables denoting the technological quality in wheat, which are influenced by the interaction between genotype and environment and by crop management (Denčić et al., 2011; Freo et al., 2011; Pinnow et al., 2013).

Protein concentration in wheat grains is one of the most important variables in the analysis of quality attributes and is influenced by edaphoclimatic conditions such as temperature and availability of water and nutrients (Garrido-Lestache et al., 2004; Hrušková et al., 2006). High temperatures during the grain filling period increase protein concentration, but reduce protein functionality (Gooding et al., 2003; Labuschagne et al., 2009). These effects lead to changes in gluten strength and also in the sodium dodecyl sulfate sedimentation test (SDSS) (Tahir et al., 2006). Likewise, the minimum temperature is a factor influencing flour yield determination, falling number, gluten strength and SDSS (Guarienti et al., 2004).

Plant nutritional status also affects the industrial quality of wheat. Higher nitrogen $(\mathrm{N})$ availability generally leads to higher protein concentration in wheat grains (Boehm et al., 2004). However, the increase in protein concentration and gluten strength may be higher when $\mathrm{N}$ fertilization is performed in specific phases, adopting the splitting of $\mathrm{N}$ doses along the development of the wheat plant (Fuertes-Mendizábal et al., 2010).

Delayed $\mathrm{N}$ fertilization in wheat is often criticized, because the accumulated protein may not be functional, leading to insignificant gains in terms of gluten strength. In addition, the industrial quality of wheat for brazilian genotypes is not usually measured by the protein concentration in the grains (Vázquez et al., 2012). The present study aimed to evaluate the influence of $\mathrm{N}$ fertilization, environment and cultivars on protein concentration, SDSS and falling number in four wheat cultivars.

\section{Material ANd Methods}

The experiments were carried out in the field during two agricultural years in two wheat-producing regions of the Paraná state: i) Londrina (23⒉ $22^{\prime} 9^{\prime \prime} \mathrm{S}, 51^{\circ} 10^{\prime} 13^{\prime \prime} \mathrm{W} ; 549 \mathrm{~m}$

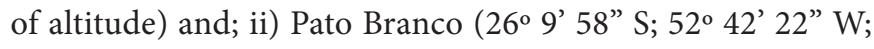
$749 \mathrm{~m}$ of altitude). Both localities have a predominant $\mathrm{Cfa}$ climate and soil classified as Oxisol. The locality of Londrina is in the region of value of cultivation and use (VCU) 3 (hot, moderately dry and low), while Pato Branco is located in the region of VCU 2 (moderately hot, humid and low).

The cultivars tested were IPR Catuara TM, BRS Gaivota, Quartzo and CD 120. The environments were coded as: environments E1 (Londrina 2011) and E2 (Londrina 2012), and environments E3 (Pato Branco 2011) and E4 (Pato Branco 2012). The cultivar IPR Catuara TM belongs to the Improver class (average alveograph energy (W) of $34010^{-4} \mathrm{~J}$ ), of early cycle and originated from LD 875/IPR 85. The cultivar BRS Gaivota belongs to the Bread class (average W of $29010^{-4} \mathrm{~J}$ ), medium cycle and originated from BR 35/Klein H $2860 \mathrm{U}$ 12100//Sonora 64/BR 23. The cultivar Quartzo belongs to the Bread class (average $\mathrm{W}$ of $27010^{-4} \mathrm{~J}$ ), medium cycle and originated from Onix/Avante. The cultivar CD 120 belongs to the Basic class (average $\mathrm{W}$ of $11110^{-4} \mathrm{~J}$ ), medium cycle and originated from RUBI/CD 105.

Soil chemical characteristics at $0-20 \mathrm{~cm}$ layer (Table 1 ). The experimental design used was randomized blocks in split plot scheme, with four repetitions. Four wheat cultivars (main plot) were tested under six forms of $\mathrm{N}$ management (subplots) in four environments (locality and year grouped).

Sowing was mechanically performed in the no-tillage system on soybean straw in both localities. Each experimental unit consisted of six rows spaced by $0.17 \mathrm{~m}$ with seven meters in length and observation area of $5.1 \mathrm{~m}^{2}$; the distance between each subplot was $1 \mathrm{~m}$. Seeds were treated with Imidacloprid (Gaucho FS) at dose of $70 \mathrm{~mL}$ (commercial product) for every $100 \mathrm{~kg}$ of seeds. Basal fertilization was $300 \mathrm{~kg} \mathrm{ha}^{-1}$ of the 10-30-10 formulation in Londrina, whereas $350 \mathrm{~kg} \mathrm{ha}^{-1}$ of the $08-20-20$ formulation in Pato Branco. Plant density was 330 plants $\mathrm{m}^{-2}$ in all environmental conditions.

The forms of $\mathrm{N}$ management were: $\mathrm{N} 1$ - without topdressing $\mathrm{N} ; \mathrm{N} 2-60 \mathrm{~kg} \mathrm{ha}^{-1}$ of $\mathrm{N}$ in the form of urea applied at tillering; $\mathrm{N} 3-80 \mathrm{~kg} \mathrm{ha}^{-1}$ of $\mathrm{N}$ in the form of urea, applying 60 and $20 \mathrm{~kg} \mathrm{ha}^{-1}$ at tillering and booting, respectively; $\mathrm{N} 4-100 \mathrm{~kg} \mathrm{ha}^{-1}$ of $\mathrm{N}$ in the form of urea, applied at 60 and $40 \mathrm{~kg} \mathrm{ha}^{-1}$ at tillering and booting, respectively; $\mathrm{N} 5-80 \mathrm{~kg} \mathrm{ha}^{-1}$ of N, applied at 60 $\mathrm{kg} \mathrm{ha}^{-1}$ of $\mathrm{N}$ in the form of urea at tillering and $20 \mathrm{~kg} \mathrm{ha}^{-1}$ of N in the form of ammonium sulfate at booting; $\mathrm{N} 6-100 \mathrm{~kg} \mathrm{ha}^{-1}$ of $\mathrm{N}$, applied at $60 \mathrm{~kg} \mathrm{ha}^{-1}$ of $\mathrm{N}$ in the form of urea at tillering and $40 \mathrm{~kg} \mathrm{ha}^{-1}$ of $\mathrm{N}$ in the form of ammonium sulfate at booting.

In the E1 environment, after $\mathrm{N}$ fertilization, the experiment was irrigated with a water depth of approximately $15 \mathrm{~mm}$. The other crop managements, such as the control of weed, insects and diseases, were performed according to the technical recommendations for wheat cultivation. The climatic conditions of each of environment are shown in Figure 1.

The accumulated precipitation was approximately 320 and $540 \mathrm{~mm}$ in the environments E1 and E2, respectively (Figure 1). However, in the year 2012 there was precipitation of 200 $\mathrm{mm}$ in only one day, during the heading of the crop, followed by a dry period until the harvest. In the environments E3 and E4, the accumulated precipitations were approximately 1050 and $515 \mathrm{~mm}$, and in $\mathrm{E} 4$ there was a long period of drought. For temperature, there was a greater variation between the two

Table 1. Chemical characteristics of $0-20 \mathrm{~cm}$ soil layer of different environments

\begin{tabular}{|c|c|c|c|c|}
\hline \multirow{2}{*}{ Characteristic } & \multicolumn{4}{|c|}{ Environment ${ }^{1}$} \\
\hline & $E_{1}$ & $\overline{E_{2}}$ & $E_{3}$ & $\mathbf{E}_{4}$ \\
\hline$P\left(\mathrm{mg} \mathrm{dm}^{-3}\right)$ & 21.10 & 24.50 & 18.06 & 16.70 \\
\hline $\mathrm{pH}\left(\mathrm{CaCl}_{2}\right)$ & 5.1 & 5.3 & 5.6 & 5.2 \\
\hline $\mathrm{Al}\left(\mathrm{cmol}_{\mathrm{G}} \mathrm{dm}^{-3}\right)$ & 0 & 0 & 0 & 0 \\
\hline $\mathrm{H}+\mathrm{Al}\left(\mathrm{cmol}_{\mathrm{c}} \mathrm{dm}^{-3}\right)$ & 6.20 & 5.34 & 5.01 & 5.01 \\
\hline $\mathrm{Ca}\left(\mathrm{cmol}_{\mathrm{c}} \mathrm{dm}^{-3}\right)$ & 5.72 & 5.35 & 7.56 & 6.50 \\
\hline $\mathrm{Mg}\left(\mathrm{cmol}_{\mathrm{c}} \mathrm{dm}^{-3}\right)$ & 2.26 & 2.87 & 3.45 & 2.70 \\
\hline $\mathrm{K}\left(\mathrm{cmol}_{\mathrm{c}} \mathrm{dm}^{-3}\right)$ & 0.18 & 0.88 & 0.28 & 0.30 \\
\hline $\mathrm{SB}\left(\mathrm{cmol}_{\mathrm{c}} \mathrm{dm}^{-3}\right)$ & 8.16 & 9.00 & 11.29 & 9.50 \\
\hline CEC $\left(\mathrm{cmol}_{\mathrm{c}} \mathrm{dm}^{-3}\right)$ & 14.36 & 14.34 & 16.30 & 14.51 \\
\hline V (\%) & 56.82 & 62.76 & 69.26 & 65.47 \\
\hline SAl (\%) & 0 & 0 & 0 & 0 \\
\hline OM (\%) & 1.70 & 1.90 & 5.36 & 5.20 \\
\hline
\end{tabular}

Environment $\mathrm{E}_{1}$ (Londrina 2011), $\mathrm{E}_{2}$ (Londrina 2011), $\mathrm{E}_{3}$ (Pato Branco 2011) $\mathrm{E}_{4}$ (Pato Branco 2012) 

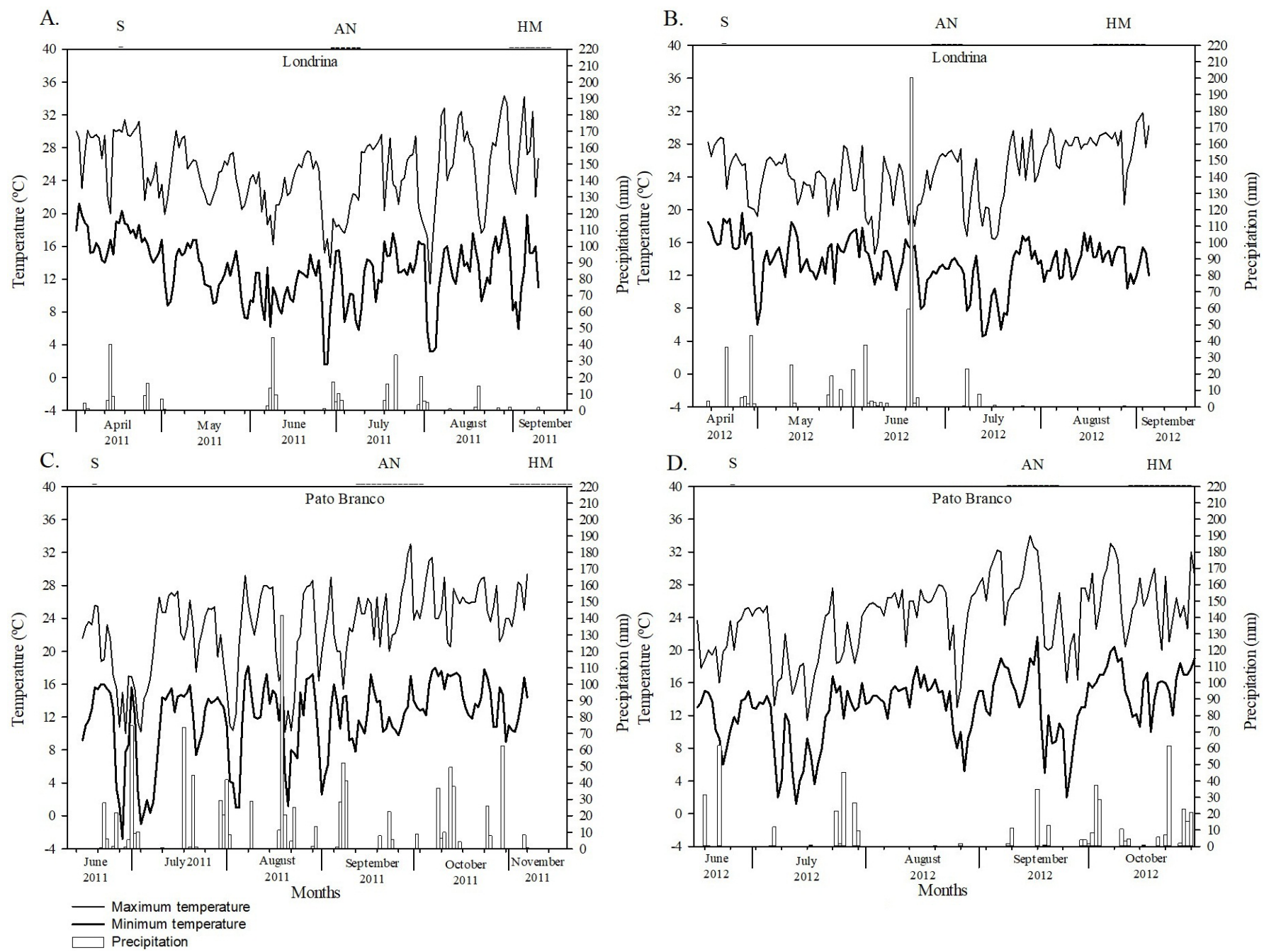

S - Sowing; AN - Anthesis; HM - Harvest maturity. Source: IAPAR, 2011-2012

Figure 1. Precipitation and minimum and maximum temperature for the environments E1 - Londrina 2011 (A), E2 - Londrina 2012 (B), E3 - Pato Branco 2011 (C) and E4 - Pato Branco 2012 (D)

sites (Londrina and Pato Branco). Such considerable variation in precipitation and temperature between the environments leads to changes in the quality of wheat produced.

The following evaluations were carried out: a) grain yield (GY), determined after mechanical harvesting of the observation area, based on the grain mass in each experimental unit estimated in $\mathrm{kg} \mathrm{ha}^{-1}$, at $13 \%$ moisture content; b) protein content (\%), determined by near-infrared reflectance (NIR) spectrophotometry. The NIR calibration curves were constructed in the Ecophysiology Laboratory of the Instituto Agronômico do Paraná (IAPAR); c) SDSS test (mL), according to the methodology proposed by Dick \& Quick (1983); d) falling number, which aims to verify the alpha-amylase enzyme activity in order to detect damage caused by germination in the ear, determined using $7 \mathrm{~g}$ of whole flour, corrected to $14 \%$ moisture, in duplicate, and the results were expressed in seconds.

A combined analysis of variance (ANOVA) for the four environments was carried out for all evaluations performed. When significant effects were observed, means were compared by Tukey test at $p \leq 0.05$. Associations between the response variables of interest were analyzed using Pearson's correlation at $\mathrm{p} \leq 0.05$.

\section{Results AND Discussion}

The low values of the coefficient of variation indicate that the inferences made are reliable and indicate high experimental precision. Nitrogen was the main cause of variation for the SDSS and FN tests, whereas for protein concentration the effect of the environment was more pronounced (Table 2).

The environment influenced the protein content (PC) of the cultivars IPR Catuara TM and Quartzo at all managements of $\mathrm{N}$ fertilization, whereas the PC of the cultivars BRS Gaivota and $\mathrm{CD} 120$ was not influenced by the environment, regardless of the $\mathrm{N}$ managements (Table 3). $\mathrm{N}$ fertilization did not significantly influence the PC of the cultivars BRS Gaivota and Quartzo in any of the environments. The concentration of proteins in wheat grains, especially glutenins, is one of the most important variables in the analysis of quality attributes in wheat (Pirozi et al., 2008). The protein content was influenced by the interaction of cultivars $\mathrm{x}$ nitrogen $\mathrm{x}$ environments $(\mathrm{C} \times$ $\mathrm{N} \times \mathrm{E}$ ) (Tables 3 and 4 ).

For the cultivars IPR Catuara TM and CD 120, the effect of $\mathrm{N}$ management on $\mathrm{PC}$ is variable between each environment, and the PC of the cultivar CD 120 was not influenced by $\mathrm{N}$ management when cultivated in Londrina (environments E1 and E2). On the other hand, the PC of the cultivars BRS Gaivota 
Table 2. Analysis of variance for protein content (PC), sodium dodecyl sulfate sedimentation (SDSS) test and falling number (FN) of four wheat cultivars in six forms of nitrogen management and four environments

\begin{tabular}{|c|c|c|c|c|}
\hline \multirow{2}{*}{ S.V. } & \multirow{2}{*}{ DF } & \multicolumn{3}{|c|}{ Mean square } \\
\hline & & PC & SDSS & FN \\
\hline Blocks & 12 & $1.21 E+00(0.65)$ & $4.34 \mathrm{E}+00(0.76)$ & $1.66 \mathrm{E}+05(<0.01)$ \\
\hline Environments - $\mathrm{E}$ & 3 & $8.37 \mathrm{E}+01(<0.01)$ & $1.69 \mathrm{E}+02(<0.01)$ & $1.28 \mathrm{E}+06(<0.01)$ \\
\hline Cultivars - C & 3 & $3.49 \mathrm{E}+01(<0.01)$ & $1.75 \mathrm{E}+02(<0.01)$ & $5.09 \mathrm{E}+04(<0.01)$ \\
\hline $\mathrm{E} \times \mathrm{C}$ & 9 & $1.77 \mathrm{E}+01(<0.01)$ & $2.05 \mathrm{E}+01(<0.01)$ & $1.36 \mathrm{E}+04(<0.01)$ \\
\hline Residual (a) & 36 & $1.51 \mathrm{E}+00$ & $6.38 \mathrm{E}+00$ & $1.65 E+03$ \\
\hline Nitrogen - N & 5 & $7.65 \mathrm{E}+00(<0.01)$ & $9.91 \mathrm{E}+00(<0.01)$ & $5.48 \mathrm{E}+03(<0.01)$ \\
\hline $\mathrm{E} \times \mathrm{N}$ & 15 & $3.64 \mathrm{E}+00(<0.01)$ & $1.26 \mathrm{E}+00(0.51)$ & $1.21 \mathrm{E}+03(0.50)$ \\
\hline $\mathrm{C} \times \mathrm{N}$ & 15 & $1.35 \mathrm{E}+00(0.48)$ & $1.95 \mathrm{E}+00(0.12)$ & $6.83 \mathrm{E}+02(0.91)$ \\
\hline$E \times C \times N$ & 45 & $2.19 \mathrm{E}+00(0.02)$ & $1.71 \mathrm{E}+00(0.12)$ & $1.84 \mathrm{E}+03(0.23)$ \\
\hline Residual (b) & 240 & $1.38 \mathrm{E}+00$ & $1.33 \mathrm{E}+00$ & $1.26 \mathrm{E}+03$ \\
\hline $\mathrm{CV}_{\mathrm{a}}(\%)$ & & 6.47 & 17.0 & 9.33 \\
\hline$C V_{b}(\%)$ & & 6.19 & 7.75 & 8.16 \\
\hline Mean & & $19 \%$ & $14.86 \mathrm{~mL}$ & $4.35 \mathrm{~s}$ \\
\hline
\end{tabular}

S.V. - Source of variation; DF - Degrees of freedom; $\mathrm{CV}_{\mathrm{a}}(\%)$ and $\mathrm{CV}_{\mathrm{b}}(\%)$ - Coefficients of variation for plot and subplot, respectively; The values in parenthesis correspond to p-value

Table 3. Comparison of means for protein content - PC (\%) under six nitrogen managements and four cultivation environments in four wheat cultivars

\begin{tabular}{|c|c|c|c|c|}
\hline Nitrogen & $E 1^{1}$ & E2 & E3 & E4 \\
\hline \multicolumn{5}{|c|}{ IPR Catuara TM } \\
\hline $\mathrm{N} 1^{2}$ & $16.7 \mathrm{Bb}$ & $19.2 \mathrm{aB}$ & $18.9 \mathrm{abA}$ & $19.2 \mathrm{aAB}$ \\
\hline N2 & $18.7 \mathrm{bcAB}$ & $20.2 \mathrm{abAB}$ & $17.3 \mathrm{cA}$ & $21.3 \mathrm{aA}$ \\
\hline N3 & $19.0 \mathrm{bcAB}$ & $21.3 \mathrm{aAB}$ & $17.5 \mathrm{cA}$ & $19.8 \mathrm{abAB}$ \\
\hline N4 & 19.6 bA & $21.8 \mathrm{aA}$ & $18.5 \mathrm{bA}$ & $19.9 \mathrm{ab} A \mathrm{~B}$ \\
\hline N5 & $19.1 \mathrm{abAB}$ & 20.9 aAB & $17.7 \mathrm{bA}$ & $19.2 \mathrm{abAB}$ \\
\hline N6 & $19.6 \mathrm{abA}$ & $21.1 \mathrm{aAB}$ & $18.6 \mathrm{bA}$ & $17.8 \mathrm{bB}$ \\
\hline \multicolumn{5}{|c|}{ Quartzo } \\
\hline N1 & $15.3 \mathrm{cA}$ & $16.8 \mathrm{bcA}$ & $18.2 \mathrm{abA}$ & $20.2 \mathrm{aA}$ \\
\hline N2 & $17.1 \mathrm{bA}$ & $17.5 \mathrm{abA}$ & $17.6 \mathrm{abA}$ & $19.5 \mathrm{aA}$ \\
\hline N3 & $17.1 \mathrm{bA}$ & $18.2 \mathrm{abA}$ & $16.9 \mathrm{bA}$ & $20.1 \mathrm{aA}$ \\
\hline N4 & $16.2 \mathrm{bA}$ & $18.7 \mathrm{aA}$ & $19.2 \mathrm{aA}$ & $19.2 \mathrm{aA}$ \\
\hline N5 & $16.7 \mathrm{cA}$ & $18.0 \mathrm{bcA}$ & $19.0 \mathrm{abA}$ & $20.5 \mathrm{aA}$ \\
\hline N6 & $16.5 \mathrm{bA}$ & $18.3 \mathrm{abA}$ & $19.0 \mathrm{aA}$ & $20.3 \mathrm{aA}$ \\
\hline \multicolumn{5}{|c|}{ BRS Gaivota } \\
\hline $\mathrm{N} 1^{2}$ & $18.7 \mathrm{aA}$ & $19.7 \mathrm{aA}$ & $18.9 \mathrm{aA}$ & $19.6 \mathrm{aA}$ \\
\hline N2 & $19.6 \mathrm{aA}$ & $20.4 \mathrm{aA}$ & $18.8 \mathrm{aA}$ & $20.6 \mathrm{aA}$ \\
\hline N3 & $19.5 \mathrm{abA}$ & $20.5 \mathrm{aA}$ & $18.1 \mathrm{bA}$ & $19.9 \mathrm{abA}$ \\
\hline N4 & $20.1 \mathrm{aA}$ & $20.9 \mathrm{aA}$ & $17.0 \mathrm{bA}$ & $19.7 \mathrm{aA}$ \\
\hline N5 & $20.2 \mathrm{aA}$ & $20.7 \mathrm{aA}$ & $18.7 \mathrm{aA}$ & $19.6 \mathrm{aA}$ \\
\hline N6 & $19.9 \mathrm{aA}$ & $21.4 \mathrm{aA}$ & $17.1 \mathrm{bA}$ & $20.3 \mathrm{aA}$ \\
\hline \multicolumn{5}{|c|}{ CD 120} \\
\hline N1 & $17.1 \mathrm{bA}$ & $19.4 \mathrm{aA}$ & $17.0 \mathrm{bABC}$ & $19.1 \mathrm{abAB}$ \\
\hline N2 & $18.1 \mathrm{bA}$ & $20.3 \mathrm{aA}$ & $18.6 \mathrm{abABC}$ & $19.7 \mathrm{abAB}$ \\
\hline N3 & $19.9 \mathrm{abA}$ & $20.3 \mathrm{aA}$ & 16.7 cBC & $17.8 \mathrm{bcB}$ \\
\hline N4 & $18.7 \mathrm{aA}$ & $20.6 \mathrm{aA}$ & $18.9 \mathrm{aAB}$ & $19.4 \mathrm{aAB}$ \\
\hline N5 & $19.0 \mathrm{aA}$ & $20.2 \mathrm{aA}$ & 16.3 bC & $20.9 \mathrm{aA}$ \\
\hline N6 & $18.6 \mathrm{aA}$ & $20.6 \mathrm{aA}$ & $19.1 \mathrm{aA}$ & $20.2 \mathrm{aA}$ \\
\hline
\end{tabular}

Lowercase letters compare environments and uppercase letters compare $N$ managements for the same cultivar; Means followed by the same letter do not differ by Tukey test at $\mathrm{p} \leq 0.05$ ${ }^{1}$ E1 - 2011 and E2 - 2012 (Londrina); E3 - 2011 and E4 - 2012 (Pato Branco)

${ }^{2} \mathrm{~N} 1$ (without topdressing N); N2 (60 kg of $\mathrm{N} \mathrm{ha}^{-1}$ in the form of urea at tillering); N3 (60 $\mathrm{kg}$ of $\mathrm{N} \mathrm{ha}^{-1}$ at tillering and $20 \mathrm{~kg}$ of $\mathrm{N} \mathrm{ha}^{-1}$ at booting in the form of urea); $\mathrm{N} 4$ (60 kg of N $\mathrm{ha}^{-1}$ at tillering and $40 \mathrm{~kg}$ of $\mathrm{N} \mathrm{ha}^{-1}$ at booting in the form of urea); $\mathrm{N} 5$ ( $60 \mathrm{~kg}$ of N ha-1 in the form of urea at tillering and $20 \mathrm{~kg}$ of $\mathrm{N} \mathrm{ha}^{-1}$ in the form of ammonium sulfate at booting) and N6 (60 kg of N ha-1 in the form of urea at tillering and $40 \mathrm{~kg}^{-1} \mathrm{~N} \mathrm{ha}^{-1}$ in the form of ammonium sulfate at booting)

and Quartzo were not influenced by the $\mathrm{N}$ management in any of the environments. For the cultivation in Londrina (environments E1 and E2), the cultivar BRS Gaivota had the highest $\mathrm{PC}$, regardless of the $\mathrm{N}$ management, significantly differing only from the cultivar. On the other hand, in Pato Branco (environments E3 and E4), the PC did not differ between cultivars in any of the $\mathrm{N}$ managements. Despite the positive effect of $\mathrm{N}$ on $\mathrm{PC}$, it was observed that there is a
Table 4. Comparison of means for protein content - PC (\%) under six forms of nitrogen management and four wheat cultivars in four cultivation environments

\begin{tabular}{ccccc}
\hline Nitrogen & $\begin{array}{c}\text { IPR } \\
\text { Catuara TM }\end{array}$ & $\begin{array}{c}\text { BRS } \\
\text { Gaivota } \\
\text { EnvironmentE1 }\end{array}$ & Quartzo & CD 120 \\
\hline N12 & $16.7 \mathrm{ab}$ & $18.7 \mathrm{a}$ & $15.3 \mathrm{~b}$ & $17.1 \mathrm{ab}$ \\
N2 & $18.7 \mathrm{ab}$ & $19.6 \mathrm{a}$ & $17.1 \mathrm{~b}$ & $18.1 \mathrm{ab}$ \\
N3 & $19.0 \mathrm{ab}$ & $19.5 \mathrm{a}$ & $17.1 \mathrm{~b}$ & $19.9 \mathrm{ab}$ \\
N4 & $19.6 \mathrm{a}$ & $20.1 \mathrm{a}$ & $16.2 \mathrm{~b}$ & $18.7 \mathrm{a}$ \\
N5 & $19.1 \mathrm{a}$ & $20.2 \mathrm{a}$ & $16.7 \mathrm{~b}$ & $19.0 \mathrm{a}$ \\
N6 & $19.6 \mathrm{a}$ & $19.9 \mathrm{a}$ & $16.5 \mathrm{~b}$ & $18.6 \mathrm{ab}$ \\
\hline \multicolumn{5}{c}{ Environment E2 } \\
\hline N1 & $19.2 \mathrm{a}$ & $19.7 \mathrm{a}$ & $16.8 \mathrm{~b}$ & $19.4 \mathrm{a}$ \\
N2 & $20.2 \mathrm{a}$ & $20.4 \mathrm{a}$ & $17.5 \mathrm{~b}$ & $20.3 \mathrm{a}$ \\
N3 & $21.3 \mathrm{a}$ & $20.5 \mathrm{a}$ & $18.2 \mathrm{~b}$ & $20.3 \mathrm{ab}$ \\
N4 & $21.8 \mathrm{a}$ & $20.9 \mathrm{a}$ & $18.7 \mathrm{~b}$ & $20.6 \mathrm{ab}$ \\
N5 & $20.9 \mathrm{a}$ & $20.7 \mathrm{a}$ & $18.0 \mathrm{~b}$ & $20.2 \mathrm{a}$ \\
N6 & $21.1 \mathrm{a}$ & $21.4 \mathrm{a}$ & $18.3 \mathrm{~b}$ & $20.6 \mathrm{a}$ \\
\hline \multicolumn{5}{c}{ Environment E3 } \\
N1 & $18.9 \mathrm{a}$ & $18.9 \mathrm{a}$ & $18.2 \mathrm{a}$ & $17.0 \mathrm{a}$ \\
N2 & $17.3 \mathrm{a}$ & $18.8 \mathrm{a}$ & $17.6 \mathrm{a}$ & $18.6 \mathrm{a}$ \\
N3 & $17.5 \mathrm{a}$ & $18.1 \mathrm{a}$ & $16.9 \mathrm{a}$ & $16.7 \mathrm{a}$ \\
N4 & $18.5 \mathrm{ab}$ & $17.0 \mathrm{~b}$ & $19.2 \mathrm{a}$ & $18.9 \mathrm{ab}$ \\
N5 & $17.7 \mathrm{ab}$ & $18.7 \mathrm{a}$ & $19.0 \mathrm{a}$ & $16.3 \mathrm{~b}$ \\
N6 & $18.6 \mathrm{a}$ & $17.1 \mathrm{a}$ & $19.0 \mathrm{a}$ & $19.1 \mathrm{a}$ \\
\hline \multicolumn{5}{c}{ EnvironmentE4 } \\
N1 & $19.2 \mathrm{a}$ & $19.6 \mathrm{a}$ & $20.2 \mathrm{a}$ & $19.1 \mathrm{a}$ \\
N2 & $21.3 \mathrm{a}$ & $20.6 \mathrm{a}$ & $19.5 \mathrm{a}$ & $19.7 \mathrm{a}$ \\
N3 & $19.8 \mathrm{ab}$ & $19.9 \mathrm{ab}$ & $20.1 \mathrm{a}$ & $17.8 \mathrm{~b}$ \\
N4 & $19.9 \mathrm{a}$ & $19.7 \mathrm{a}$ & $19.2 \mathrm{a}$ & $19.4 \mathrm{a}$ \\
N5 & $19.2 \mathrm{a}$ & $19.6 \mathrm{a}$ & $20.5 \mathrm{a}$ & $20.9 \mathrm{a}$ \\
N6 & $17.8 \mathrm{~b}$ & $20.3 \mathrm{a}$ & $20.3 \mathrm{a}$ & $20.2 \mathrm{a}$ \\
\hline
\end{tabular}

Lowercase letters compare the effect of cultivars for the same environment; Means followed by the same letter do not differ by Tukey test at $\mathrm{p} \leq 0.05$

${ }^{1} \mathrm{E} 1$ - 2011 and E2 - 2012 (Londrina); E3 - 2011 and E4 - 2012 (Pato Branco)

${ }^{2} \mathrm{~N} 1$ (without topdressing $\mathrm{N}$ ); $\mathrm{N} 2$ (60 kg of $\mathrm{N} \mathrm{ha}^{-1}$ in the form of urea at tillering); N3 (60 $\mathrm{kg}$ of $\mathrm{N} \mathrm{ha}^{-1}$ at tillering and $20 \mathrm{~kg}$ of $\mathrm{N} \mathrm{ha}^{-1}$ at booting in the form of urea); $\mathrm{N} 4$ (60 kg of N $\mathrm{ha}^{-1}$ at tillering and $40 \mathrm{~kg}$ of $\mathrm{N} \mathrm{ha}^{-1}$ at booting in the form of urea); N5 (60 kg of $\mathrm{N} \mathrm{ha}^{-1}$ in the form of urea at tillering and $20 \mathrm{~kg}$ of $\mathrm{N} \mathrm{ha}^{-1}$ in the form of ammonium sulfate at booting) and $\mathrm{N} 6$ ( $60 \mathrm{~kg}$ of N ha-1 in the form of urea at tillering and $40 \mathrm{~kg}^{-1} \mathrm{~N} \mathrm{ha}^{-1}$ in the form of ammonium sulfate at booting)

different capacity to accumulate proteins in the grains among the cultivars, as reported by Ercoli et al. (2011).

The results observed in PC variability due to the environment have already been reported in the literature and can be explained by variations in temperature and rainfall (Singh et al., 2010). Vázquez et al. (2012) reported that the environmental effect on protein content variability was significantly higher than the genotypic effect. Indeed, higher temperature and low 
precipitation during grain filling in the $\mathrm{E} 4$ environment caused an increment in PC. This relationship between climatic variables and PC is quite uncertain, because some results such as those obtained by López-Bellido et al. (2001) indicate that excessive precipitation during protein accumulation in the grains results in increment in PC. However, there are authors who indicate that PC increases under low precipitation conditions (GarridoLestache et al., 2004).

Rao et al. (1993) claim that the mechanism regulating protein content is complex and that the effects of precipitation and temperature are not consistent in all places or years. Despite the protein increase under drought conditions, it should be pointed out that the increment of protein content in grains may not always result in higher quality of baking because, usually, there is an increment in the synthesis of gliadins (Hajheidari et al., 2007). These protein subunits do not have significant contribution to gluten strength. Although the previous crop in this study was soybean in all environments, it should be emphasized that the analysis of PC also depends on the $\mathrm{C} / \mathrm{N}$

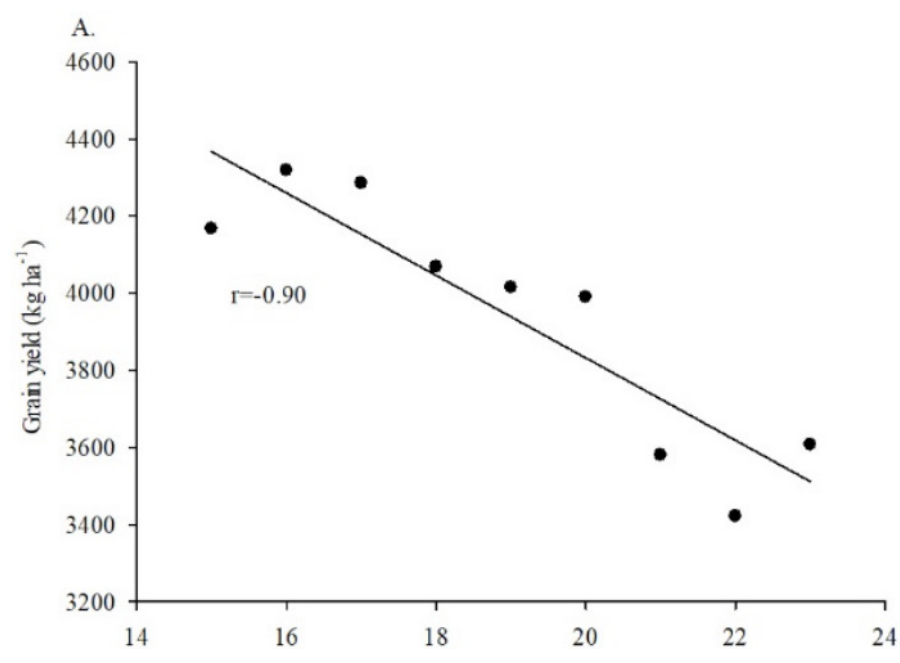

ratio of the straw (Pinnow et al., 2013). Thus, under conditions that limit $\mathrm{N}$ availability, it was observed that there is a reduction in the protein synthesis in the grains and increment of starch.

Protein content was negatively correlated $(r=-0.90)$ with wheat grain yield (Figure 2). Previous studies have reported negative relationship between grain yield and PC (Guarda et al., 2004; Śíp et al., 2013), concomitant increase in PC and grain yield (Pinnow et al., 2013) and lack of correlation (Bordes et al., 2008). Therefore, the correlation between grain yield and PC depends on factors such as environment, genotype and cultural practices (Pinnow et al., 2013; Šíp et al., 2013), so a generalization for this association is not possible.

Among the various tests to evaluate the technological suitability of flour, the SDSS test is a reliable, low-cost, quick test which requires little labor, so it can be used in the initial phases of genetic improvement (Oelofse et al., 2010).

In the sodium dodecyl sulfate sedimentation (SDSS) test, the cultivar IPR Catuara TM showed a significant difference only between the environments E1 and E3 (Table 5). The SDSS for the cultivars BRS Gaivota and CD 120 increased in

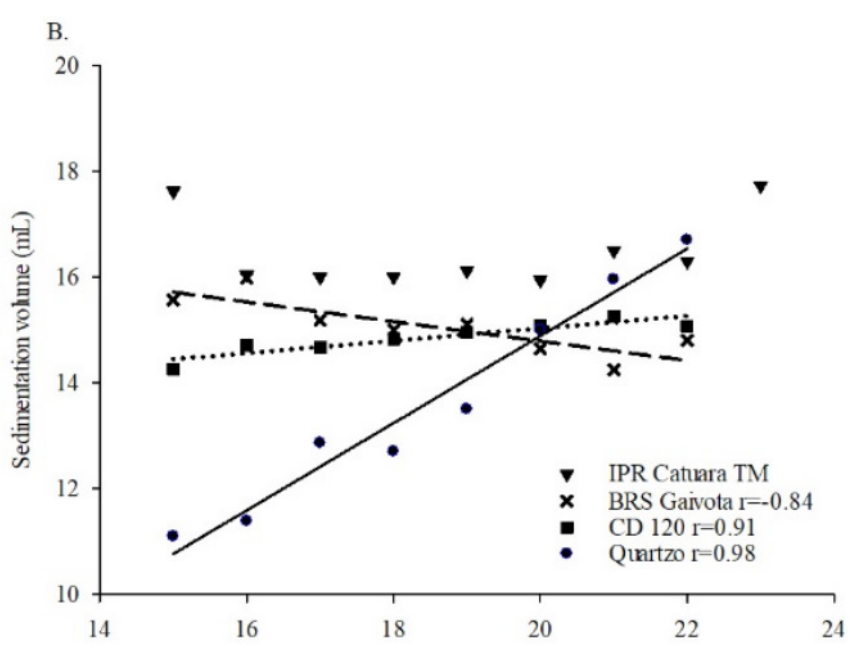

Figure 2. Pearson's correlation ( $\mathrm{r}$ ) at $\mathrm{p} \leq 0.05$ probability level for grain yield vs. protein concentration $-\mathrm{PC}(\mathrm{A})$, protein concentration and sodium dodecyl sulfate sedimentation volume - SDSS (B)

Table 5. Comparison of means for sodium dodecyl sulfate sedimentation (SDSS) test and falling number of four wheat cultivars grown in four environments and mean of the effect of topdressing nitrogen fertilization

\begin{tabular}{|c|c|c|c|c|c|c|}
\hline \multirow[b]{2}{*}{ Cultivar } & \multicolumn{4}{|c|}{ Environments ${ }^{1}$} & \multirow{2}{*}{ Nitrogen ${ }^{2}$} & \multirow[b]{2}{*}{ Means } \\
\hline & E1 & E2 & E3 & E4 & & \\
\hline \multicolumn{7}{|c|}{ Sedimentation volume - SDSS (mL) } \\
\hline IPR Catuara TM & $15.2 \mathrm{bA}$ & $16.5 \mathrm{abA}$ & $17.3 \mathrm{aA}$ & $16.8 \mathrm{abA}$ & N1 & $14.2 \mathrm{~B}$ \\
\hline BRS Gaivota & $13.7 \mathrm{bA}$ & $13.9 \mathrm{bBC}$ & $15.4 \mathrm{abA}$ & $16.1 \mathrm{aA}$ & N2 & $14.6 \mathrm{AB}$ \\
\hline Quartzo & $11.0 \mathrm{bB}$ & $12.6 \mathrm{bC}$ & $12.5 \mathrm{bB}$ & $16.6 \mathrm{aA}$ & N3 & $15.1 \mathrm{~A}$ \\
\hline \multirow[t]{3}{*}{ CD 120} & $13.4 \mathrm{bA}$ & $14.7 \mathrm{abAB}$ & $15.7 \mathrm{aA}$ & $16.4 \mathrm{aA}$ & N4 & $15.2 \mathrm{~A}$ \\
\hline & & & & & N5 & $15.0 \mathrm{~A}$ \\
\hline & & & & & N6 & $15.1 \mathrm{~A}$ \\
\hline \multicolumn{7}{|c|}{ Falling number - FN (s) } \\
\hline IPR Catuara TM & $506 \mathrm{bA}$ & 563 aA & $509 \mathrm{bB}$ & $263 \mathrm{cA}$ & N1 & $437 \mathrm{AB}$ \\
\hline BRS Gaivota & $466 \mathrm{cB}$ & $499 \mathrm{bBC}$ & $541 \mathrm{aA}$ & $262 \mathrm{dA}$ & N2 & $424 \mathrm{~B}$ \\
\hline Quartzo & $470 \mathrm{bB}$ & $517 \mathrm{aB}$ & $474 \mathrm{bC}$ & $276 \mathrm{cA}$ & N3 & $432 \mathrm{~B}$ \\
\hline \multirow[t]{3}{*}{ CD 120} & $433 \mathrm{bc}$ & $472 \mathrm{Ac}$ & $457 a b C$ & $257 \mathrm{cA}$ & N4 & $429 B$ \\
\hline & & & & & N5 & $450 \mathrm{~A}$ \\
\hline & & & & & N6 & $440 \mathrm{AB}$ \\
\hline
\end{tabular}

Lowercase letters compare in the row and uppercase letters compare in the column; Means followed by the same letter do not differ by Tukey test at $\mathrm{p} \leq 0.05$

${ }^{1}$ E1- 2011 and E2 - 2012 (Londrina); E3 - 2011 and E4 - 2012 (Pato Branco)

${ }^{2} \mathrm{~N} 1$ (without topdressing $\mathrm{N}$ ); $\mathrm{N} 2$ ( $60 \mathrm{~kg}$ of $\mathrm{N} \mathrm{ha}^{-1}$ in the form of urea at tillering); $\mathrm{N} 3$ ( $60 \mathrm{~kg}$ of $\mathrm{N} \mathrm{ha}^{-1}$ at tillering and $20 \mathrm{~kg}$ of $\mathrm{N}$ ha ${ }^{-1}$ at booting in the form of urea); $\mathrm{N} 4$ (60 $\mathrm{kg}$ of $\mathrm{N}$ $\mathrm{ha}^{-1}$ at tillering and $40 \mathrm{~kg}$ of $\mathrm{N} \mathrm{ha}^{-1}$ at booting in the form of urea); N5 (60 kg of N ha-1 in the form of urea at tillering and $20 \mathrm{~kg}^{-1} \mathrm{~N} \mathrm{ha}{ }^{-1}$ in the form of ammonium sulfate at booting) and $\mathrm{N} 6\left(60 \mathrm{~kg}\right.$ of $\mathrm{N} \mathrm{ha}^{-1}$ in the form of urea at tillering and $40 \mathrm{~kg}$ of N ha-1 in the form of ammonium sulfate at booting) 
the environments E3 and E4. Similarly, the E4 environment promoted the highest SDSS for the cultivar Quartzo. In the environments E1, E2 and E3, the worst performance was that of the cultivar Quartzo. On the other hand, no significant difference was observed in the SDSS between the cultivars in the E4 environment. Regarding the forms of $\mathrm{N}$ management, it became evident that the $\mathrm{N}$ doses of 80 and $100 \mathrm{~kg} \mathrm{ha}^{-1}$ (urea or ammonium sulfate) increase SDSS, differing significantly from the control (without topdressing N).

The treatments with topdressing $\mathrm{N}$ did not differ in relation to the SDSS test. Ozturk \& Aydin (2004) reported that an increase in sedimentation in the SDSS test due to water deficit can be explained by an increase in PC, mainly due to the higher $\mathrm{N}$ accumulation rates and lower carbohydrate accumulation rates. Therefore, the environmental effect on the SDSS can be misinterpreted because changes in the environment alter PC, and any change in PC invariably has influence on SDSS.

In the Pearson's correlation analysis between SDSS and PC, all cultivars, except IPR Catuara TM, showed significant correlation (Figure 2). Results observed by Oelofse et al. (2010) indicate that SDSS is influenced by PC, but the magnitude of the effect varies according to the genotype. The correlation between SDSS and PC of the cultivar Quartzo was high $(r=0.98)$.

The SDSS value reflects the quality of the protein (gluten strength), but it can be influenced by PC (Oelofse et al., 2010; Li et al., 2013). Considering that PC tends to increase under abiotic stress (Li et al., 2013), changes in SDSS value influenced by changes in PC were expected in the present study. Indeed, there was an increment in the SDSS values when the environments are compared. However, the SDSS values of the cultivars IPR Catuara TM, BRS Gaivota and CD 120 were less influenced by protein content.

The increments observed in SDSS (IPR Catuara TM, BRS Gaivota and CD 120) cannot be associated only with changes in PC. Therefore, the differences in the trends of these cultivars in relation to SDSS may have been influenced by possible differences in the proportions of gluten proteins accumulated under the different environmental conditions (Li et al., 2013).

The results for the falling number (FN) demonstrate that, regardless of the cultivar, the E4 environment led to the lowest value for characteristic (Table 5), resulting from the occurrence of rains close to the harvest (Figure 1). The cultivar IPR Catuara TM showed the highest FN for the cultivation in Londrina (environments E1 and E2), whereas in the E3 environment the cultivar BRS Gaivota had the highest FN; in the E4 environment, the FN was not significantly influenced by cultivars.

The FN was positively influenced by the application of ammonium sulfate at the booting stage (NS), differing from the treatments that received only urea. However, the FN did not differ from that of the control (N1) in any of the forms of $\mathrm{N}$ management. According to Kindred et al. (2005), the effect of $\mathrm{N}$ on the $\mathrm{FN}$ is not frequent, but these authors observed a significant effect. The same authors claim that the observed effect of $\mathrm{N}$ on the $\mathrm{FN}$ is a characteristic that depends on interaction between genotype and $\mathrm{N}$ doses. Therefore, depending on the set of genotypes, it is possible to observe more pronounced effects of $\mathrm{N}$ on the $\mathrm{FN}$.

\section{Conclusions}

1. Protein content in wheat is influenced by the interaction between cultivars, nitrogen management sources and by the environmental conditions.

2. The protein content of the cultivars BRS Gaivota and Quartzo is not influenced by the topdressing nitrogen management in any of the evaluated environments.

3. Sodium dodecyl sulfate sedimentation volume and falling number in wheat are influenced by the interaction between cultivar and environment and also by the nitrogen management.

4. The falling number is not different between cultivars when the environment is conducive to pre-harvest sprouting.

5. Topdressing nitrogen management influences the falling number.

\section{Literature Cited}

Boehm, D. J.; Berzonsky, W. A.; Bhattacharya, M. Influence of nitrogen fertilizer treatments on spring wheat (Triticum aestivum L.) flour characteristics and effect on fresh and frozen dough quality. Cereal Chemistry, v.81, p.51-54, 2004. https://doi.org/10.1094/ CCHEM.2004.81.1.51

Bordes, J.; Branlard, G.; Oury, F. X.; Charmet, G.; Balfourier, F. Agronomic characteristics, grain quality and flour rheology of 372 bread wheat in a worldwide core collection. Journal of Cereal Science, v.48, p.569-579, 2008. https://doi.org/10.1016/j. jcs.2008.05.005

Denčić, S.; Mladenov, N.; Kobiljski, B. Effects of genotype and environment on breadmaking quality in wheat. International Journal of Plant Production, v.5, p.71-82, 2011.

Dick, J.; Quick, J. A modified screening test for rapid estimation of gluten strength in early-generation durum wheat breeding lines. Cereal Chemical, v.60, p.315-318, 1983.

Ercoli, L.; Lulli, L.; Arduini, I.; Mariotti, M.; Masoni, A. Durum wheat grain yield and quality as affected by $S$ rate under Mediterranean conditions. European Journal of Agronomy, v.35, p.63-70, 2011. https://doi.org/10.1016/j.eja.2011.03.007

Freo, J. D.; Rosso, N. D.; Moraes, L. B. D. de; Dias, A. R. G.; Elias, M. C.; Gutkoski, L. C. Physicochemical properties and silicon content in wheat flour treated with diatomaceous earth and conventionally stored. Journal of Stored Products Research, v.47, p.316-320, 2011. https://doi.org/10.1016/j.jspr.2011.05.001

Fuertes-Mendizábal, T.; Aizpurua, A.; González-Moro, M. B.; Estavillo, J. M. Improving wheat breadmaking quality by splitting the N fertilizer rate. European Journal Agronomy, v.33, p.52-61, 2010. https://doi.org/10.1016/j.eja.2010.03.001

Garrido-Lestache, E.; López-Bellido, R. J.; López-Bellido, L. Effect of $\mathrm{N}$ rate, timing and splitting and $\mathrm{N}$ type on bread-making quality in hard red spring wheat under rainfed Mediterranean conditions. Field Crops Research, v.85, p.213-236, 2004. https:// doi.org/10.1016/S0378-4290(03)00167-9

Gooding, M. J.; Ellist, R. H.; Shewry, P. R.; Schafield, J. D. Effects of restricted water availability and increased temperature on the grain filling, drying and quality of winter wheat. Journal of Cereal Science, v.37, p.295-309, 2003. https://doi.org/10.1006/ jcrs.2002.0501 
Guarda, G.; Padovan, S.; Delogu, G. Grain yield, nitrogen-use efficiency and baking quality of old and modern Italian breadwheat cultivars grown at different nitrogen levels. European Journal of Agronomy, v.21, p.181-192, 2004. https://doi. org/10.1016/j.eja.2003.08.001

Guarienti, E. M.; Ciacco, C. F.; Cunha, G. R. da; Duca, L. de J. A. del; Camargo, C. M. de O. Influência das temperaturas mínima e máxima em características de qualidade industrial e em rendimento de grãos de trigo. Ciência e Tecnologia de Alimentos, v.24, p.505-515, 2004. https://doi.org/10.1590/S010120612004000400005

Hajheidari, M.; Eivazi, A.; Buchanan, B. B.; Wong, J. H.; Majidi, I.; Salekdeh, G. H. Proteomics uncovers a role for redox in drought tolerance in wheat. Journal of Proteome Research, v.6, p.14511460, 2007. https://doi.org/10.1021/pr060570j

Hrušková, M.; Švec, I; Jirsa, O. Correlation between milling and baking parameters of wheat varieties. Journal of Food Engineering, v.77, p.439-444, 2006. https://doi.org/10.1016/j. jfoodeng.2005.07.011

Kindred, D. R.; Gooding, M. J.; Ellis, R. H. Nitrogen fertilizer and seed rate effects on Hagberg falling number of hybrid wheats and their parents are associated with $\alpha$-amylase activity, grain cavity size and dormancy. Journal of the Science Food and Agriculture, v.85, p.727-742, 2005. https://doi.org/10.1002/jsfa.2025

Labuschagne, M. T.; Elago, O.; Koen, E. The influence of temperature extremes on some quality and starch characteristics in bread, biscuit and durum wheat. Journal of Cereal Science, v.49, p.184189, 2009. https://doi.org/10.1016/j.jcs.2008.09.001

López-Bellido, L.; Lopez-Bellido, R. J.; Castillo, J. E.; Lopez-Bellido, F. J. Effects of long-term tillage crop rotation and nitrogen fertilization on bread-making quality of hard red spring wheat. Field Crop Research, v.72, p.197-210, 2001. https://doi. org/10.1016/S0378-4290(01)00177-0

Li, Y. F.; Wu, Y.; Hernandez-Espinosa, N.; Peña, R. J. Heat and drought stress on durum wheat: Responses of genotypes, yield, and quality parameters. Journal of Cereal Science, v.57, p.398-404, 2013. https://doi.org/10.1016/j.jcs.2013.01.005
Oelofse, R. M.; Labuschagne, M. T.; Deventer, C. S. van. Influencing factors of sodium dodecyl sulfate sedimentation in bread wheat. Journal of Cereal Science, v.52, p.96-99, 2010. https://doi. org/10.1016/j.jcs.2010.03.010

Ozturk, A.; Aydin, F. Effect of water stress at various growth stages on some quality characteristics of winter wheat. Journal of Agronomy \& Crop Science, v.190, p.93-99, 2004. https://doi. org/10.1046/j.1439-037X.2003.00080.x

Pinnow, C.; Benin, G.; Viola, R.; Silva, C. L. da; Gutkoski, L. C.; Cassol, L. C. Qualidade industrial do trigo em resposta à adubação verde e doses de nitrogênio. Bragantia, v.72, p.20-28, 2013. https://doi. org/10.1590/S0006-87052013005000019

Pirozi, M. R.; Margiotta, B.; Lafiandar, D. E.; Macritchie, F. Composition of polymeric proteins and bread-making quality of wheat lines with allelic HMW_GLU differing in number of cysteines. Journal of Cereal Science, v.48, p.117-122, 2008. https:// doi.org/10.1016/j.jcs.2007.08.011

Rao, A. C. S.; Smith, J. L.; Jandhyala, V. K.; Papendick, R. I.; Parr, J. F. Cultivar and climatic effects on the protein content of soft white winter wheat. Agronomy Journal, v.85, p.1023-1028, 1993. https:// doi.org/10.2134/agronj1993.00021962008500050013x

Singh, S.; Nag, S. K.; Kundu, S. S.; Maity, S. B. Relative intake, eating pattern, nutrient digestibility, nitrogen metabolism, fermentation pattern and growth performance of lambs fed organically and inorganically produced cowpea hay-barley grain diets. Tropical Grasslands, v.44, p.55-61, 2010.

Šíp, V.; Vavera, R.; Chrpová, J.; Kusá, H.; Růžk, P. Winter wheat and quality related to tillage practice, input level and environmental conditions. Soil \& Tillage Reserarch, v.132, p.77-85, 2013. https:// doi.org/10.1016/j.still.2013.05.002

Tahir, I. S. A.; Nakata, N.; Ali, A. M. Genotypic and temperature effects on wheat grain yield and quality in a hot irrigated environment. Plant Breeding, v.125, p.323-330, 2006. https://doi.org/10.1111/ j.1439-0523.2006.01236.x

Vázquez, D.; Berger, A. G.; Cuniberti, M.; Bainotti, C.; Miranda, M. Z. de; Scheeren, P. L.; Jobet, C.; Zúñiga, J.; Cabrera, G.; Verges, R.; Peña, R. J. Influence of cultivar and environment on quality of Latin American wheats. Journal of Cereal Science, v.56, p.196-203, 2012. https://doi.org/10.1016/j.jcs.2012.03.004 